\title{
Effect of Water Management on Mycoherbicidal Activity of Exserohilum monoceras against Echinochloa oryzicola
}

\author{
Hiroshi Tsukamoto*, Mitsuya Tsuda**, Masatoshi GohbarA* \\ and Takane FUJIMORI*
}

\begin{abstract}
Factors affecting the herbicidal activity of Exserohilum monoceras JTB-808 against Echinochloa oryzicola young seedlings were examined using a drop inoculation method under greenhouse conditions. The herbicidal activity of the fungus correlated with water management practices. High herbicidal activity was produced by increasing the depth and duration of water flooding. When $10^{5}$ conidia/ $100 \mathrm{~cm}^{2}$ were introduced to a pot filled with water to a depth of $7 \mathrm{~cm}$ or $9 \mathrm{~cm}$, more than $95 \%$ of plants were killed, and the dry weight of the plants was reduced by over $95 \%$ at 21 days after inoculation. A water depth of $7 \mathrm{~cm}$ with 7 or more days of flooding gave almost the same results at 21 days after inoculation. When the flooding was prolonged to 14 days, the plants were completely destroyed. Shallow depths or short flooding duration were not effective. Lesion development under submergence was examined on the first leaf of E. oryzicola after inoculation with conidia embedded in low melting-temperature agarose gel. When inoculated leaves were kept under submergence for 1, 2 or 3 days, collapsed lesions enlarged to $14.3,78.7$ and $95.3 \%$ of the leaf area of each sample, respectively, by 10 days after inoculation. The results show that submergence of the host plants promoted lesion development, which led to high mycoherbicidal activity.
\end{abstract}

(Received April 6, 1998 ; Accepted July 16, 1998)

Key words : mycoherbicide, Exserohilum monoceras, Echinochloa oryzicola, flooding, submergence, lesion development.

\section{INTRODUCTION}

Bioherbicides using plant pathogens as agents of weed control have been shown to be an alternative to chemical herbicides. At present, at least five bioherbicides are registered: De Vine (Phytophthora palmivora) for stranglervine (Morrenia odorata) ${ }^{2,13)}$; Collego (Colletotrichum gloeosporioides f. sp. aeschynomene) for northern jointvetch $(\text { Aeschynomene virginica })^{3)}$; BioMal $(C$. gloeosporioides f. sp. malvae) for round-leaved mallow (Malva

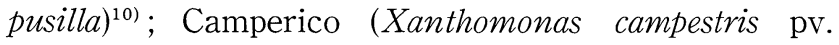
poae) for annual bluegrass (Poa annua $)^{7,11}$; and Biochon (Chondrostereum purpureum) for stump sprouting in black cherry (Prunus serotina) and many other woody weeds ${ }^{4,5}$. In rice-growing areas, the Echinochloa species is one of the most important paddy weeds but few reports concern the development of alternative methods for weeding it.

In our previous study ${ }^{16}$, we selected Exserohilum monoceras as the most promising candidate against Echinochloa weeds from among several species obtained from diseased Echinochloa plants in the field. Of the strains examined, E. monoceras JTB-808 is the most virulent representative of the species and is a good conidiator under culture conditions.

In general, the success of fungal infection depends on the retention of a dew period needed for the anchoring of the propagules and establishment of the disease. Because the dew period outdoors cannot always be expected to continue throughout fungal penetration, this natural constraint must be overcome in field applications. Thus, mycoherbicidal activity is affected by these conditions. Many mycoherbicides need at least $6 \mathrm{hr}$ and sometimes over $24 \mathrm{hr}$ of dew period for enough herbicidal activity ${ }^{11}$. E. monoceras JTB-808 also needs at least $24 \mathrm{hr}$ of dew period at $25^{\circ} \mathrm{C}$ to kill $90 \%$ of host plants $(\text { E. crus-galli var. crus-galli })^{16)}$. Likewise, for an $E$. monoceras Philippines isolate, 8-, 12- and 16-hr dew periods at $25^{\circ} \mathrm{C}$ were required for complete mortality of E. glabrescence (=E. crus-galli var. formosensis), E. crus-galli $(=E$. crus-galli var. crus-galli $)$ and E. colona, respectively ${ }^{20)}$. However, the dew period ranged from 0 $\mathrm{hr}$ to $13.5 \mathrm{hr}$ (mean : $8.9 \mathrm{hr}$ ) at a paddy field in Fukushima

* Plant Protection Research Laboratory, Japan Tobacco Inc., 6-2, Umegaoka, Aoba-ku, Yokohama 227-8512, Japan 日本たばこ産業株式会社植物保護開発センター

** Graduate School of Agriculture, Kyoto University, Kitashirakawa Oiwake-cho, Sakyo-ku, Kyoto 606-8502, Japan 京都大学大学院農学研究科 
Prefecture in Japan on July $15-31$ in $1974^{6}$. Therefore, the dew duration in the field is sometimes too short for E. monoceras to kill host plants.

We previously solved the dew period problem by dropping a suspension of $10^{5}$ conidia $/ 100 \mathrm{~cm}^{2}$ of $E$. monoceras JTB-808 onto the surface of water in a pot which was flooded to a depth of $7 \mathrm{~cm}$ and contained submerged seedling at the first-leaf stage $(1-\mathrm{LS})^{16)}$. The fungus killed the following Echinochloa species which are indigenous to Japanese paddy fields : E. oryzicola, $E$. crus-galli var. crus-galli, E. crus-galli var. formosensis and $E$. colona ${ }^{9,17)}$.

The purpose of this study was to investigate the effect of water management factors, such as water depth and duration of flooding, on the herbicidal activity of $E$. monoceras JTB-808 against E. oryzicola. Furthermore, we discuss mycoherbicidal activities in flooded conditions by a study of lesion development on the first leaves of $E$. oryzicola inoculated with conidia and kept in a submerged condition. A preliminary report of this work was presented at the Annual Meeting of the Phytopathological Society of Japan in 199715).

\section{MATERIALS AND METHODS}

Fungal isolate and inoculum Exserohilum monoceras JTB-808 was incubated on an oatmeal sucrose agar plate at $25^{\circ} \mathrm{C}$ in continuous dark for approximately 3 weeks. Conidial suspensions were prepared as described in a previous report ${ }^{16)}$ with the concentration of Tween 20 changed to $0.04 \%$ (v/v). They were adjusted to a suitable density with a haemacytometer (FuchsRosenthal, Kayagaki Irikakogyo, Japan).

Test plants Echinochloa oryzicola $\mathrm{C}$ type, kindly provided by Y. Yamasue, was propagated and used. The 1-LS plants were prepared in a pot $\left(100 \mathrm{~cm}^{2}\right)$ as described in a previous report ${ }^{16)}$. They were kept in a greenhouse at $25 \pm 2^{\circ} \mathrm{C}$ in the daytime and $20 \pm 2^{\circ} \mathrm{C}$ at night, at $70 \pm$ $20 \%$ RH. In each experimental block, triplicate pots were used.

Mycoherbicidal activity To examine the effect of the depth of water flooding on herbicidal activity, $5 \mathrm{ml}$ of conidial suspension $\left(2 \times 10^{4}\right.$ or $2 \times 10^{5}$ conidia $\left./ \mathrm{ml}\right)$ was pipetted onto the surface of water in the pot (20 plants/ pot). The depth of the water in the pot was adjusted to $1,3,5,7$ or $9 \mathrm{~cm}$ above the soil surface by adding distilled water. Tap water was not used in this study, because the chlorine in tap water suppressed lesion development. Test plants at the 1-LS were completely submerged by flooding to a depth of $5 \mathrm{~cm}$. The water depth was maintained until 21 days after inoculation.

To examine the effect of flood duration, $5 \mathrm{ml}$ of conidial suspension $\left(2 \times 10^{4}\right.$ and $2 \times 10^{5}$ conidia/ml $)$ was pipetted into pots ( 20 plants/pot) in which plants were submerged in $7 \mathrm{~cm}$ of water. To allow sedimentation of the conidia, the pot was left standing for about $30 \mathrm{~min}$. Subsequently, to test 0 day's of flooding, the flood water was drained with a siphon and the pot was refilled to a depth of $1 \mathrm{~cm}$ with distilled water. In the same manner, the water was changed at the end of the tests for $1,2,3$, 4, 7, 14 and 21 days of flooding.

The number of surviving plants was counted $7,10,14$, 17 and 21 days after inoculation. The plant shoots were harvested at 21 days after inoculation and dried at $65^{\circ} \mathrm{C}$ for 5 days in an oven. The dry weight was measured and expressed per pot.

Observation of lesion development under submerged conditions One $\mathrm{ml}$ of $2 \times 10^{5}$ conidia $/ \mathrm{ml}$ $0.04 \%$ Tween 20 and $1 \mathrm{ml}$ of $2 \%$ low melting-temperature agarose (NuSieve GTG, FMC BioProducts, ME, USA) in distilled water kept at $40^{\circ} \mathrm{C}$ were mixed just before inoculation. Three $\mu l$ of the mixture was pipetted onto the center of the upper surface of the 1-LS leaf. Three pots (10 plants/pot) were used in each treatment. After the inoculum had gelled and adhered to the leaf surface, the pots were gently flooded with distilled water to a depth of $9 \mathrm{~cm}$ to submerge the test plants and incubated in a dew chamber at $25^{\circ} \mathrm{C}$ under dark conditions. The flood water was reduced to $1 \mathrm{~cm}$ depth $0,1,2$ or 3 days after inoculation, then pots were transferred to the greenhouse. As a positive control, pots containing plants which were not submerged but contained $1 \mathrm{~cm}$ water depth were used, and they were kept in the dew chamber in the same manner. Lesion development was evaluated dialy as the percentage of necrotic area to total leaf area for 10 days after inoculation.

\section{RESULTS}

\section{Effect of water depth on mycoherbicidal activity}

The test plants showed systemic necrosis within 7 days after inoculation and were covered with visible fungal mycelia at 9 days (Fig. 1A). The severity of the disease symptoms was related to the water depth. The percentage of dead plants increased with an increase in water depth (Figs. 2A and 2B). At a depth of $9 \mathrm{~cm}$, the fungus killed $23.3 \%$ of the test plants at 7 days and completely destroyed them by 14 days in the blocks inoculated with $10^{5}$ conidia/ $100 \mathrm{~cm}^{2}$ (Fig. 2A). When the water depth was $7 \mathrm{~cm}$ or less, the fungus did not kill all of the plants even after 21 days of incubation (Fig. 2A).

Conidial density also clearly affected herbicidal activity. Inoculations with $10^{6}$ conidia $/ 100 \mathrm{~cm}^{2}$ produced greater and more rapid eradication of the test plants compared to those with $10^{5}$ conidia/ $100 \mathrm{~cm}^{2}$. In the case of inoculation with $10^{6}$ conidia $/ 100 \mathrm{~cm}^{2}$, water depths of $5 \mathrm{~cm}$ or greater also achieved complete eradication by 21 days after inoculation (Fig. 2B).

The dry weight of surviving plants was also used as a weed control index. In these cases the control index was higher than that expressed by the percentage of dead plants. For example, in the inoculations with $10^{5}$ and $10^{6}$ conidia/ $100 \mathrm{~cm}^{2}$ at water depths of $1 \mathrm{~cm}$, plant dry weight was reduced to $43.7 \%$ and $59.0 \%$ respectively, compared with control blocks, although the percentage of dead plants was only $6.7 \%$ and $11.7 \%$, respectively, at 

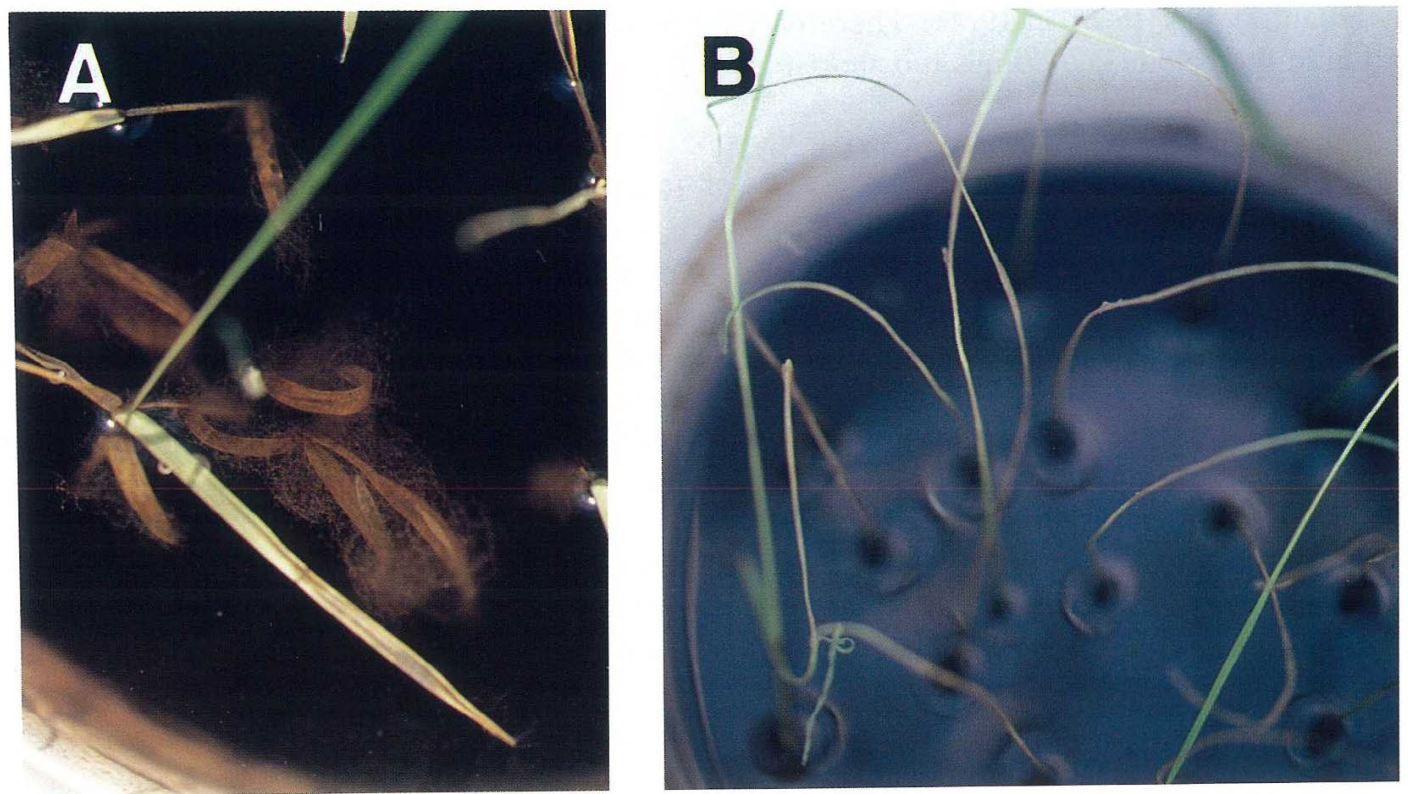

Fig. 1. Symptoms caused by Exserohilum monoceras JTB-808 on Echinochloa oryzicola under submergence. A, Diseased plants surrounded with hyphae 9 days after inoculation with conidia; B, Whitish blight symptom after submergence for 7 days and exposure to air for 2 days.

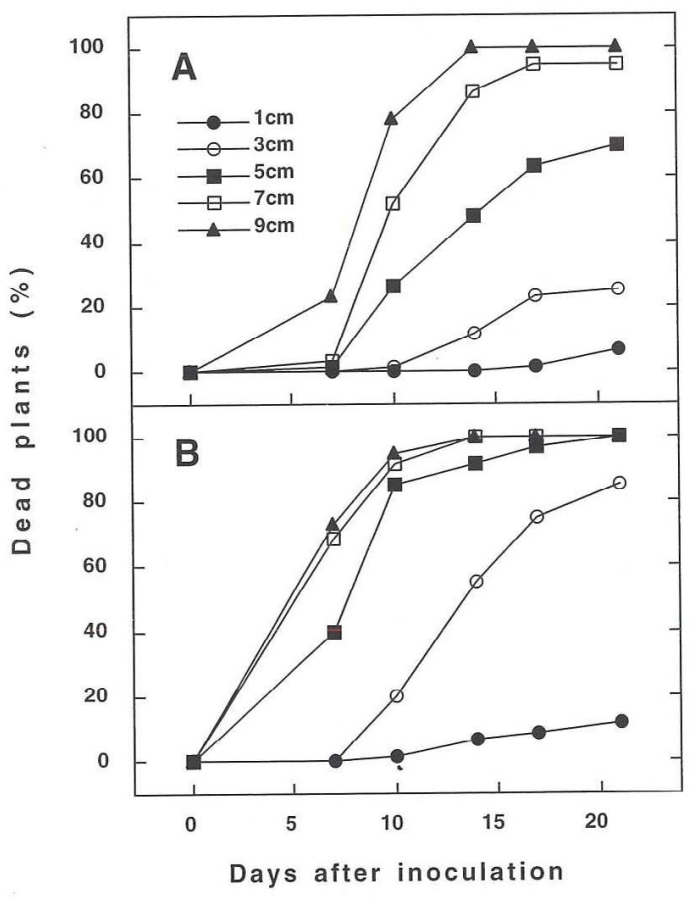

Fig. 2. Effect of water depth on herbicidal activity of Exserohilum monoceras against Echinochloa oryzicola after drop inoculation. E. oryzicola, flooded to different depths, was drop-inoculated with a conidial suspension of $E$. monoceras JTB-808. The water depth in each pot was maintained for 21 days. No plants died in the treatment with $0.04 \%$ Tween 20 as a negative control. A, $10^{5}$ conidia/ $100 \mathrm{~cm}^{2} ; \mathrm{B}, 10^{6}$ conidia/ $100 \mathrm{~cm}^{2}$.
Table 1. Effect of water depth on survival of Echinochloa oryzicola after inoculation with Exserohilum monoceras JTB-808 at different application rates after 3 weeks

\begin{tabular}{|c|c|c|c|}
\hline \multirow{3}{*}{$\begin{array}{c}\text { Water } \\
\text { depth } \\
(\mathrm{cm})\end{array}$} & \multicolumn{3}{|c|}{ Plant dry weight (mg) and percent controla) } \\
\hline & \multicolumn{3}{|c|}{ Inoculum rate (conidia/ $\left.100 \mathrm{~cm}^{2}\right)^{\mathrm{b})}$} \\
\hline & 0 & $10^{5}$ & $10^{6}$ \\
\hline 1 & $377.7 \pm 26.6^{\mathrm{c})}$ & $212.7 \pm 20.7(43.7)$ & $155.0 \pm 37.6(59.0)$ \\
\hline 3 & $387.0 \pm 16.3$ & $141.0 \pm 38.4(63.6)$ & $18.0 \pm 6.4 \quad(95.3)$ \\
\hline 5 & $308.7 \pm 32.2$ & $59.7 \pm 33.4(80.7)$ & $0.0 \pm 0.0(100.0)$ \\
\hline 7 & $221.3+14.2$ & $10.3 \pm 7.4 \quad(95.3)$ & $0.0 \pm 0.0(100.0)$ \\
\hline 9 & $204.7 \pm 6.6$ & $0.0 \pm 0.0(100.0)$ & $0.0 \pm 0.0(100.0)$ \\
\hline
\end{tabular}

a) Values in parentheses show percentage control based on the dry weight of surviving plants, regardless of health status, compared to the negative control in each row.

b) No plants died as a result of treatment with $0.04 \%$ Tween 20 (negative control).

c) Mean \pm standard deviation of plant dry weight from triplicate pots, 20 plants/pot.

21 days (Figs. 2A, B and Table 1). The fungus reduced plant dry weight by more than $80 \%$ in all blocks after 21 days inoculation, except in the cases of both conidial densities at a depth of $1 \mathrm{~cm}$ and $10^{5}$ conidia/ $100 \mathrm{~cm}^{2}$ at a depth of $3 \mathrm{~cm}$ (Table 1). Deep flooding without fungal inocula also reduced the plant dry weight (Table 1) but did not lead to plant death and it did not suppress the development of the leaf stages.

Host plants at the 1-LS were completely submerged at depths $5 \mathrm{~cm}$ and over, whereas at $1 \mathrm{~cm}$ the first leaf was not submerged and at $3 \mathrm{~cm}$ only $20-50 \%$ of the area of the leaf was submerged. The first leaves in $5-9 \mathrm{~cm}$ of water continued to be either submerged or floated on the 


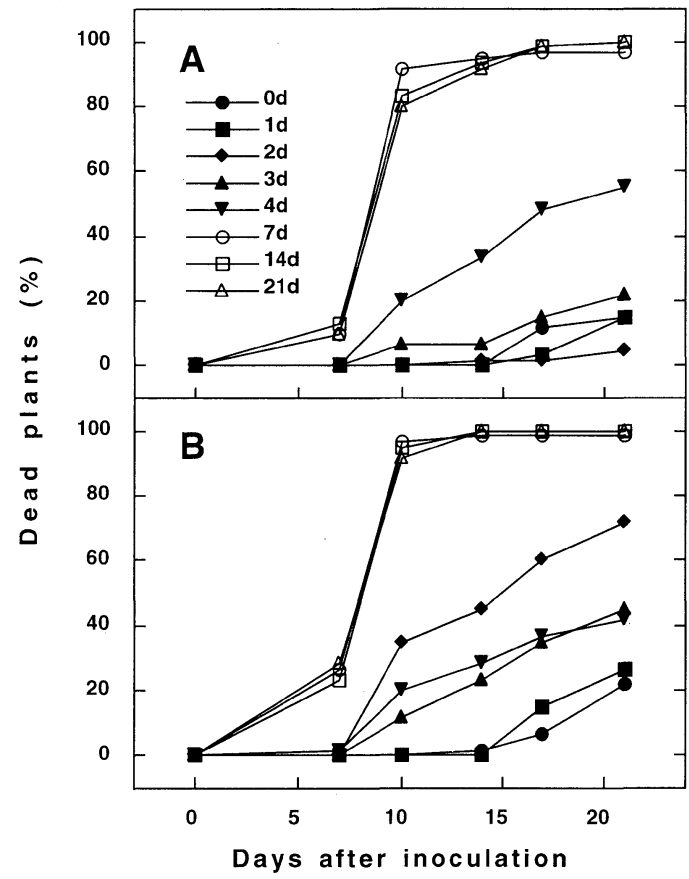

Fig. 3. Effect of flood duration on herbicidal activity of Exserohilum monoceras against Echinochloa oryzicola after drop inoculation. E. oryzicola, after drop inoculation with a conidial suspension of E. monoceras JTB-808, was submerged in water for different durations. Water depth remained constant at $7 \mathrm{~cm}$ until the day listed, and was then maintained at $1 \mathrm{~cm}$ until 21 days. No plants died in the treatment with $0.04 \%$ Tween 20 as a negative control. A, $10^{5}$ conidia/ $100 \mathrm{~cm}^{2} ; \mathrm{B}, 10^{6}$ conidia $/ 100 \mathrm{~cm}^{2}$.

Table 2. Effect of flooding duration at a depth of $7 \mathrm{~cm}$ on survival of Echinochloa oryzicola 3 weeks after inoculations with Exserohilum monoceras JTB-808 at different application rates

\begin{tabular}{clccc}
\hline \hline \multirow{2}{*}{$\begin{array}{c}\text { Flooding } \\
\text { duration }\end{array}$} & \multicolumn{4}{c}{ Plant dry weight $(\mathrm{mg})$ and percent control ${ }^{\mathrm{a})}$} \\
\cline { 2 - 5 } (days) & \multicolumn{4}{c}{ Inoculum rate (conidia $\left./ 100 \mathrm{~cm}^{2}\right)^{\mathrm{b})}$} \\
\hline 0 & $541.7 \pm 12.7^{\text {c) }}$ & $211.7 \pm 20.5(60.9)$ & $160.3 \pm 45.0(70.4)$ \\
1 & $441.7 \pm 6.1$ & $203.3 \pm 41.6(54.0)$ & $106.0 \pm 32.6(76.0)$ \\
2 & $421.3 \pm 35.7$ & $156.7 \pm 18.2(62.8)$ & $36.7 \pm 18.6(91.3)$ \\
3 & $358.0 \pm 2.9$ & $118.3 \pm 30.7(66.9)$ & $74.0 \pm 52.9(79.3)$ \\
4 & $324.7 \pm 23.8$ & $52.3 \pm 13.6(83.9)$ & $58.7 \pm 36.0$ & $(81.9)$ \\
7 & $270.3 \pm 12.8$ & $6.7 \pm 9.4(97.5)$ & $3.7 \pm 5.2$ & $(98.6)$ \\
14 & $293.3 \pm 18.8$ & $0.0 \pm 0.0(100.0)$ & $0.0 \pm 0.0(100.0)$ \\
21 & $328.3 \pm 17.0$ & $0.0 \pm 0.0(100.0)$ & $0.0 \pm 0.0(100.0)$ \\
\hline
\end{tabular}

a) Values in parentheses show percentage control based on the dry weight of surviving plants, regardless of health status, compared to the negative control in each row.

b) No plants died as a result of treatment with $0.04 \%$ Tween 20 (negative control).

c) Mean \pm standard deviation of plant dry weight from triplicate pots, 20 plants/pot. water until 21 days later.

\section{Effect of flooding duration on mycoherbicidal activity}

Systemic brownish lesions which formed on submerged plants changed to a whitish blight once the water had been drained (Fig. 1B). As with water depth, flooding duration also strongly affected the weed-killing activity. The number of dead plants increased with longer periods of flooding (Figs. 3A and B). With flooding periods less than 7 days, the percentage of dead plants did not reach $80 \%$ (Figs. $3 \mathrm{~A}$ and $\mathrm{B}$ ). However, the weed control index from the dry weight of surviving plants was higher than that expressed by the number of dead plants. In flooding of 4 days and more, plant dry weight was reduced by over $80 \%$ (Table 2 ).

Lesion development under submergence and in dew chamber conditions

Exserohilum monoceras JTB-808 induced watersoaked lesions and systemic wilt after inoculation with agarose-embedded conidia under submergence and in dew conditions. Lesion development correlated with submergence duration. One day of submergence developed the lesions to $14.3 \%$ of the total leaf area, whereas that for 2 and 3 days developed them to $78.7 \%$ and $95.3 \%$, respectively, measured 10 days after inoculation (Fig. 4). Long periods in a dew chamber also enhanced the expansion of the lesion sizes. In all cases, lesion development was superior in dew chamber treatments. This development was most remarkable in the case of the 1-day treatment. Significant differences in lesion

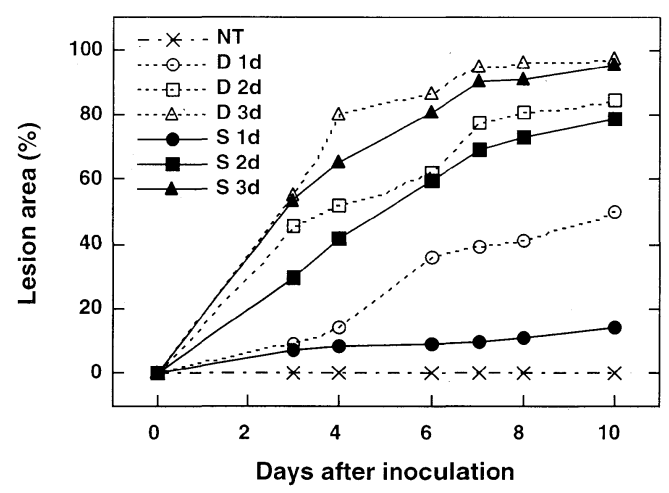

Fig. 4. Effects of duration of submergence and dew on lesion development. Low-melting temperature agarose-embedded conidia of Exserohilum monoceras JTB-808 were dropped on the surface of the first leaf of Echinochloa oryzicola and plants were incubated under either submergence or dew for $0,1,2$ or 3 days. Lesion area (\%) was evaluated until 10 days after inoculation. Figures are an average of the lesion areas on the first leaves of 30 plants. Abbreviation: NT represents no treatment with dew or submergence; D 1d, D 2d and D 3d represent dew treatments for 1,2 and 3 days, respectively; $\mathrm{S}$ $1 d, S 2 d$ and S 3d represent submergence plus dew treatments for 1, 2 and 3 days, respectively. 
development were observed between the following treatments under submergence and those in the dew chamber: between the 1-day submergence and dew chamber treatments at 4 to 10 days after inoculation, the 2 -day treatments at 3 days and the 3-day treatments at 4 days, according to Student's $t$-test $(p=0.01)$.

\section{DISCUSSION}

Deep flooding enhanced the herbicidal activity against Echinochloa oryzicola when conidia of Exserohilum monoceras JTB-808 were introduced to flooded host plants at the 1 -LS. With $10^{5}$ conidia $/ 100 \mathrm{~cm}^{2}$, herbicidal activity was inconsistent at shallow flooding depths. Thus, the boundary of activity was considered to lie between depths of 5 and $7 \mathrm{~cm}$ (Fig. 2 and Table 1). Fewer conidia would have adhered at water depths less than 5 $\mathrm{cm}$ because the first leaves were out of the water and the submerged leaf area was small. The same number of conidia would be expected to land on submerged plants flooded to depths of $5 \mathrm{~cm}$ and over after drop inoculation, but the $9-\mathrm{cm}$ flood showed the strongest herbicidal activity. This result could be explained by the fact that whole plants were submerged for a longer duration at 9 $\mathrm{cm}$ in depth and lesion development on the inoculated leaf was better under submerged conditions. For the same reason, herbicidal activity would increase as flooding lasted longer (Fig. 3 and Table 2).

Why does the lesion expand under submergence? We can assume that submergence promotes fungal growth and/or suppresses host resistance. Submergence seems to supply the necessary water for the fungus to infect host plants and to enhance fungal growth around the host plants. In fact, fungal mycelia grew from host tissues and enveloped the host plants when they were in water (Fig. 1A). E. oryzicola can germinate and grow for long periods of time in $\mathrm{O}_{2}$-deficient submergence conditions because its metabolism shifts to an alcoholic fermentation system as the regulator of anaerobic energy production $^{8,14,18,19)}$. This condition may increase host susceptibility to fungal infection.

In the case of Bipolaris oryzae ${ }^{12)}$ and in this study the diseased lesion was expanded by keeping it in a moist chamber; high humidity seems to promote lesion development. We proved that submergence played the same role as dew conditions. However, lesion development was delayed under submergence compared with lesion development in the dew chamber. This delay will be the next area of study, because the expansion of lesions induced by foliar pathogens under water has not been studied.

We have evaluated the efficacy of $E$. monoceras JTB808 in controlling submerged Echinochloa weeds in greenhouse tests in this and previous reports ${ }^{16)}$. Drop inoculation produced high herbicidal activity when water management, with respect to depth and duration, was suitable. The following conditions are most conducive to obtaining herbicidal activity greater than a $90 \%$ reduction of plant mass: with $10^{5}$ conidia $/ 100 \mathrm{~cm}^{2}$, the flooding must be at least $7 \mathrm{~cm}$ in depth for at least 7 days; and with $10^{6}$ conidia/ $100 \mathrm{~cm}^{2}$, the water needs to be at least $3 \mathrm{~cm}$ deep for at least 21 days (Tables 1 and 2). In transplanted-rice paddy fields in Japan, flooding is commonly maintained at a depth of 3 to $5 \mathrm{~cm}$. Therefore, if the mycoherbicide at concentrations of $10^{5}$ conid$\mathrm{ia} / 100 \mathrm{~cm}^{2}$ is applied to the field, a greater depth is required for control although this depth differs from that used with chemical herbicides. Our field trials in 1993 (Koide, Niigata), 1995 (Oyama, Tochigi), 1996 and 1997 (Koide, Niigata) showed more than $90 \%$ reduction of plant dry weight after drop inoculation of conidial suspensions of E. monoceras JTB-808 to plants in a paddy submerged to a depth of 5 to $7 \mathrm{~cm}$. In the most recent field test at Koide in 1997, $10^{9}$ conidia/a killed $95.8 \%$ of plants at 27 days and produced a $97.4 \%$ reduction in plant dry weight at 42 days, and $10^{10}$ conidia/a killed $95.8 \%$ of plants at 13 days and produced a $100 \%$ reduction in plant dry weight at 42 days, compared with untreated control plots (unpublished data). By contrast, spray inoculation with an E. monoceras strain isolated from the disease in the Philippines reduced plant dry weight by only approximately $50 \%$ reduction by 28 days $^{20)}$. The two results show that drop inoculation, which is less likely to be influenced by environmental factors such as dew period, may be more suitable for control of Echinochloa weeds compared with spray inoculation in the field, although we cannot rule out the possibility that the herbicidal activity reflects differences between the strains and hosts used.

We thank Dr. Y. Yamasue (Kyoto University) for providing the Echinochloa oryzicola seeds used in this study. We are grateful to Ms. K. Shimizu for culture maintenance and technical assistance, and also acknowledge the assistance of Ms. A. Mackie in the English revision of this manuscript.

\section{Literature cited}

1. Boyette, C.D., Quimby, P.C., Jr., Caesar, A.J., Birdsall, J.L., Connick, W.J., Jr., Daigle, D.J., Jackson, M.A., Egley, G.H. and Abbas, H.K. (1996). Adjuvants, formulations, and spraying systems for improvement of mycoherbicides. Weed Technol. 10 : 637-644.

2. Burnett, H.C., Tucker, D.P.H. and Ridings, W.H. (1974). Phytophthora root and stem rot of milkweed vine. Plant Dis. Rep. 58 : 355-357.

3. Daniel, J.T., Templeton, G.E., Smith, R.J., Jr. and Fox, W.T. (1973). Biological control of northern jointvetch in rice with an endemic fungal disease. Weed Sci. 21 : 303-307.

4. De Jong, M.D., Scheepens, P.C. and Zadoks, J.C. (1990). Risk analysis for biological control : a Dutch case study in biocontrol of Prunus serotina by the fungus Chondrostereum purpureum. Plant Dis. 74 : 189-194.

5. De Jong, M.D., Wagenmakers, P.S. and Goudriaan, J. (1991). Modelling the escape of Chondrostereum purpureum spores from a larch forest with biological control 
of Prunus serotina. Neth. J. Plant Pathol. 97 : 55-61.

6. Hashimoto, A., Hirano, K. and Matsumoto, K. (1984). Studies on the forecasting of rice leaf blast development by application of the computer simulation. Subsidized Experiment (Plant Disease and Insect Pests) Bulletin 14. Spec. Bull. Fukushima Pref. Agric. Exp. Stn. 2 : 1-104 (in Japanese with English summary).

7. Imaizumi, S., Tateno, A. and Fujimori, T. (1997). Effect of Xanthomonas campestris pv. poae (JT-P482) on the growth and seed production of annual bluegrass (Poa annua L.). J. Weed Sci. Tech. 42 : 8-17.

8. Kennedy, R.A., Barrett, S.C.H., Zee, D.V. and Rumpho, M.E. (1980). Germination and seedling growth under anaerobic conditions in Echinochloa crus-galli (barnyard grass). Plant Cell Environ. 3 : 243-248.

9. Morita, H. (1996). Morphological characteristics of spikelets and panicles of Echinochloa colonum (L.) Link and lack of establishment in Kyushu island at low temperatures. Weed Res., Japan 41 : 90-97 (in Japanese with English summary).

10. Mortensen, K. (1988). The potential of an endemic fungus, Colletotrichum gloeosporioides, for biological control of round-leaved mallow (Malva pusilla) and velvetleaf (Abutilon theophrasti). Weed Sci. 36: 473478.

11. Nishino, T., Imaizumi, S., Miyabe, K., Yamada, M. and Goto, M. (1995). Xanthomonas campestris pv. poae as the causal agent of wilt symptoms on annual bluegrass in Japan. Ann. Phytopathol. Soc. Jpn. 61 : 555-561.

12. Ono, K. (1953). Morphological studies on blast and sesame leaf spot of rice plant. J. Hokuriku Agric. 2 : 177 (in Japanese with English summary).

13. Ridings, W.H. (1986). Biological control of stranglervine in citrus - a researcher's view. Weed Sci. 34 (Suppl. 1) : 31-32.

14. Rumpho, M.E. and Kennedy, R.A. (1983). Anaerobiosis in Echinochloa crus-galli (barnyard grass) seedlings. Intermediary metabolism and ethanol tolerance. Plant Physiol. 72 : 44-49.

15. Tsukamoto, H., Gohbara, M. and Fujimori, T. (1997). Effect of flooding on infection, lesion development and mycoherbicidal activity of Echinochloa spp. pathogen, Exserohilum monoceras. Ann. Phytopathol. Soc. Jpn. 63 : 216 (Abstr. in Japanese).
16. Tsukamoto, H., Gohbara, M., Tsuda, M. and Fujimori, T. (1997). Evaluation of fungal pathogens as biological control agents for the paddy weed, Echinochloa species by drop inoculation. Ann. Phytopathol. Soc. Jpn. 63 : 366-372.

17. Yabuno, T. (1975). The classification and geographical distribution of the genus Echinochloa. Weed Res., Japan 20: 97-104 (in Japanese).

18. Yamasue, Y. and Ueki, K. (1987). Seed dormancy and germination of Echinochloa oryzicola Vasing. : substantive evidences for alcohol fermentation at early germination. Weed Res., Japan 32 : 263-267.

19. Yamasue, Y., Ueki, K. and Chisaka, H. (1987). Seed dormancy and germination of Echinochloa oryzicola Vasing. : an observation through respiration and several enzyme activities. Weed Res., Japan 32 : 188-197.

20. Zhang, W.M. and Watson, A.K. (1997). Effect of dew period and temperature on the ability of Exserohilum monoceras to cause seedling mortality of Echinochloa species. Plant Dis. 81: 629-634.

\section{和 文 摘 要}

塚本浩史・津田盛也・郷原雅敏・藤森 嶺：タイヌビエ (Echinochloa oryzicola) に対する Exserohilum monoceras の除 草活性における水管理の影響

タイヌビエ (E. oryzicola) の幼植物体に対する E. monoceras JTB-808 の除草活性に影響する要因について, 温室内で滴下接 種法によって調べた。本菌の除草活性は, 水管理と関係してい た。すなわち, 湛水深および湛水期間を増加させると, 高い除草 活性が得られた。 $10^{5}$ 分生胞子 $/ 100 \mathrm{~cm}^{2}$ を $7 \mathrm{~cm}$ あるいは $9 \mathrm{~cm}$ の湛水深のポットに接種したとき，接種 21 日後 $95 \%$ 以上の植 物体が枯死し，その乾重は $95 \%$ 以上減少した。7 日間以上の 7 $\mathrm{cm}$ の湛水では,接種 21 日後にほぼ同様の結果が得られた。湛水 期間を 14 日間まで長くすると，植物体は完全に除草された。低 水深あるいは短い湛水期間では, 効果的な除草活性とならなか った。低融点アガロースゲル中に固定した分生胞子をタイヌビ エの第 1 葉に接種する方法によって, 湛水下の病斑拡大につい て調べた。1，2 あるいは 3 日間，接種葉を冠水すると，接種 10 日後までに壊死した病斑は，それぞれ葉面積の $14.3,78.7$ および 95.3\%にまで拡大した。以上の結果は, 宿主植物を冠水すること が病斑の拡大を促進し，高い除草活性に結び付いていることを 示す。 